\title{
Critical Constructivist Teaching in Good Sportsmanship Through Olympism Education: An Action Based Teacher Education Program Conducted in Sri Lanka
}

\section{Samantha Nanayakkara}

School of Sciences and Physical Education, College of Education, University of Canterbury, Christchurch, New Zealand. svj11@uclive.ac.nz

\begin{abstract}
This article explores how action research practice is used to empower teachers in critical constructivist teaching in Sri Lanka. The study that informs the article aimed to provide a broader understanding of how to empower teachers by providing opportunities to create their own teaching methods, and to disseminate the findings of teaching good sportsmanship through Olympism education. This study combined the Year Five primary teacher and the physical education teacher in the same school for the purpose of teaching good sportsmanship through Olympism for primary students. The study population comprised a representative sample of five primary and five physical education teachers. The intervention was carried out for a six-month period. Three action cycles were planned throughout the program and later modified with various strategies, according to teachers' self and interaction assessments. Data were collected through a base line survey, teachers' reflective diaries, and focus group discussions. Results revealed that once the action based Olympism education teacher training was introduced, there was a dramatic increase in the outcome of teachers' knowledge, attitudes and skills required for teaching good sportsmanship through the concept of Olympism at primary schools. Teachers were also able to reflect on their own practice and come up with useful strategies to overcome their problems. This research concluded that strategically designed and carefully managed action research programs are useful for developing and enhancing competencies in teachers in order to teach concepts of Olympism effectively.
\end{abstract}

Key words: action research, constructivism, good sportsmanship, Olympism, physical education, reflective practice, teacher education

\section{Introduction}

In order to enhance young persons' competencies for good sportsmanship in the context of the school curriculum, it is essential to experiment with the present sport education teaching-learning process and how it promotes good sportsmanship. Physical education (PE) teachers play a crucial role in teaching physical education and popularising and promoting sport in schools. Their immense contribution in the identification of sporting talent 
and its development at grass-root level in the schooling context will influence the future macro level sport performance outcomes of a country. However, teachers face many problems while promoting sport practice in the education curriculum including limited time allocation, lack of resources, and lack of in-service teacher training. Among these, the most significant problem, yet to be resolved is lack of in-service teacher training related to physical education. Even within their limited in-service teacher training, PE teachers improve their physical activity training, practice of different sports, physiological domains, health initiatives and use of new sporting equipments. Thus, in order to improve good sportsmanship among younger generation, teachers need more encouragement, guidance and help from the stakeholders to engage in tasks. Teachers need to find new ways to construct knowledge through the first hand experiences of their students. Therefore, teachers need to gain competencies in critical constructivist teaching.

Critical constructivist teaching reflects the fact that teaching, learning and knowledge production are complexly interrelated (Kincheloe, 2005). Critical constructivists believe that students' engagement in the knowledge production process at schools is more important than transmitting knowledge through memorization (Taylor, 1998). According to Kincheloe (2005) the knowledge of the classroom is constructed where students' personal experiences interact with academic knowledge. From the critical constructivist teachers' point of view, synthesis of personal experience and academic knowledge must be maintained, and this involves extremely complex pedagogy that demands extraneous work to gather different perspectives. Brosio (2000) argues that critical constructivist teacher learn to think, teach and live democratically. Reaffirming Brosio's (2000) argument, Kincheloe (2005) emphasises that the notion of critical constructivism allows teachers a critical consciousness to become emancipatory teachers whose perceptions are developed via linguistic codes, cultural settings, race, class, gender and sexual ideologies, and other often-hidden modes of power. These arguments demonstrate the importance of involving critical constructivist teaching at every level (primary/secondary) in schools. Thus, it is necessary to inquire how teachers could gain critical constructivist teaching practice in their own working environment, and what forces in teachers' lives have shaped their perceptions of critical constructivist teaching.

Generally, teachers gain pedagogical knowledge from interactive experiences with children and subject knowledge from specialist teachers (Wood and Attfield, 1996; Hewett, 2001). They also articulate that teachers not only play the roles of guides, enablers and facilitators, but also act as collaborators, colearners, researchers and reflective practitioners. Cropley and McLeod (1986) emphasised the personal characteristics, knowledge and special skills of the ideal teacher for the gifted, as well as the importance of teacher training. 
In-service training enhances teachers' own self-concept and perceived selfcompetence to a point where they would feel sufficiently confident to become actively engaged in promoting talents (McLeod and Cropley, 1989). It seems that teachers' views on teaching students to achieve good sportsmanship competencies, and the teaching approaches they utilized to do so are interrelated and directly affect the entire positive or negative learning outcome. Therefore, it is necessary to inquire the following critical issues: What are teachers' views on teaching good sportsmanship? What teaching-learning areas in the physical education curriculum encourage good sportsmanship? How could physical education teachers better transmit the knowledge, skills and attitudes on good sportsmanship to their students?

Knowledge is partisan and dynamic, and hence must be conceptualised within a multi-dimensional socio-cultural matrix including ethical and political matters (Fernandez-Balboa, 1997), Culpan (2007) points out what societies urgently need are to challenge learners to develop a strong sense of social responsibility and social justice both within and beyond the classroom. Thus, students need to recognize what is bad sportsmanship, the consequences of bad sportsmanship and why people encourage good sportsmanship. To enable teachers to develop the younger generation's good sportsmanship competencies, teachers need to develop more confidence by training to fulfil their students' requirements. Teachers must be viewed not as technicians who merely transmit their subject matter, but as transformative intellectuals who are capable of engaging in a professional reform (Ruiz and Fernandez-Balboa, 2005). Accordingly, it is important to implement teacher training programmes in sport, physical education and Olympism to achieve the goal.

Moral and ethical underpinning of sport is consistent with the ideal of Olympism (Arnold, 1979). Muller (2004) emphasised that top level Olympic achievement and optimum sporting performance can be credibly maintained only if human perfection is achieved by honesty. One of the main goals of the International Olympic Committee (IOC), (2010) is to educate young athletes on the benefits of sport for a healthy lifestyle, the social values sport can deliver, and the dangers of doping and of training to excess and/or of inactivity. Olympism has a very useful educational mandate and it is perhaps best promoted through school physical education (PE) programmes (Binder, 2005; Culpan, 2001, 2007). According to Muller (2004), Olympic education means both physical and mental education. He further emphasises that Olympic education encourages awareness among children and young people that lifelong involvement in sport leads to development and maintenance of a fulfilling sense of identity (Muller, 2004). Therefore, critical pedagogy of Olympic education would essentially help students to become more 'fully human' (Ruiz and Fernandez-Balboa, 2005). Hence, school sports should be expressly included in Olympic education (Grupe, 1997). To succeed in 
this goal, Binder (2005) argues that Olympism educators need to move away from the safety and certainty of teaching rules, penalties and universally acceptable principles, and move towards an imaginative, holistic, diverse but inclusive vision for teaching Olympic values. However, some concerns about teaching Olympism have been raised in schools. These concerns include the ways in which teachers could learn about teaching Olympism, whether it is only physical education teachers that can be involved in teaching Olympism, whether non-physical education teachers are able to teach Olympism and the nature of the currently existing barriers for teaching Olympism at schools.

The intention of this study was to identify the ways in which teachers could effectively teach good sportsmanship through Olympism education lessons in the primary classroom. I planned to use a theme-based teaching method to encourage the teachers' inventiveness in teaching, thereby create a pleasant learning environment. Among the themes developed were concepts of Olympism, good sportsmanship, and teaching strategies. The teacher training activities were planned to stimulate and develop teachers' awareness and teaching abilities in Olympism and good sportsmanship.

\section{Methodology}

This study was conducted in Sri Lanka from December 2009 to June 2010 and programmed as a process of teaching Olympism in the primary classroom. The needs analysis of the Central Province Ministry of Education, Sri Lanka, identified that the implication of Olympism education is the most neglected area in PE teacher training (MOECP, SL, 2008). The overarching aim of this study was to improve teachers' knowledge, skills and attitudes with regard to teaching good sportsmanship through the concepts of Olympism. The more specific aims of the study were four fold:

(i) To explore the ways in which teachers could become involved in teaching good sportsmanship through Olympism in Sri Lankan primary schools;

(ii) To identify, and where possible to overcome the problems of successfully teaching good sportsmanship through the Olympism curriculum;

(iii) To facilitate the teachers' reflection on, and appreciation of teaching good sportsmanship through the Olympism curriculum;

(iv) To evaluate the outcomes of the strategies that were used in the Olympism education teacher training program

Utilizing a qualitative approach, this study sought to answer the following research question: 
How can good sportsmanship be effectively taught through the concepts of Olympism in the primary classroom?

This study was conducted as an action based teacher training program by providing teachers with the opportunity to conduct the 'action research' and disseminating its findings on the teaching-learning process. The rationale for the adoption of an action research approach is a commitment to change the working practice of teachers in the classrooms. Action research also "seeks to enhance social justice in education through the maximisation of participation and a conscious mindfulness of what is fair and right" (Campbell and Groundwater-Smith, 2010). Action research is the study of a social situation with a view to improving the quality of action within it (Elliott, 1991). Action research is "a powerful tool for educational change and improvement at a local level" (Cohen, et al., 2005). Cohen et al., (2005) also emphasise that action research can "improve teaching skills, develop new methods of learning, increase powers of analysis and heighten self-awareness". Action research is not simply what teachers normally do when they teach and "it involves the systematic collection of information on which to base reflection and action" (Williams, 2000).

In this study, two Action research processes were conducted simultaneously. First, as the main researcher, I conducted an action research, about teacher training in Olympism. Secondly, teachers who participated in this study practised action research as teacher researchers in their classroom teaching. The methodology used for this research was based on Elliott's (1991) model of action research. The rationale for selecting this model was that Elliott is active in worldwide educational and other contexts and applied action research in many international educational contexts (McNiff and Whitehead, 2002). Elliott (1991; 2002) sharpened Lewin's ideas on action research cycles by highlighting key principles:

(i) The cycles of action should be carried out in real educational settings.

(ii) There should be a working hypothesis or research question developed at the beginning of the research, and this should remain flexible and open to revision until the research ends.

(iii) Research should be viewed as a form of professional development. Therefore, teachers need constantly to be involved in critical reflection on both curricula and methods

(iv) Use should be made of "triangulation" (consideration of the views of teacher, the students, and one or more external observers)

In this study, Elliott's ideas on action research were employed in three cycles of action, and all researchers (I and teacher researchers) followed the cycles of action. 
The study critically examined and developed teaching and learning strategies of Olympism education by determining action plans, implementations and experiences at each cycle. Critical reflections and evaluation of each cycle were used to plan the next cycle. See figure 1 below.

Diagnosing the focal problem

Identifying changing areas

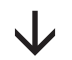

Identifying appropriate strategies

\section{Implementing strategies}

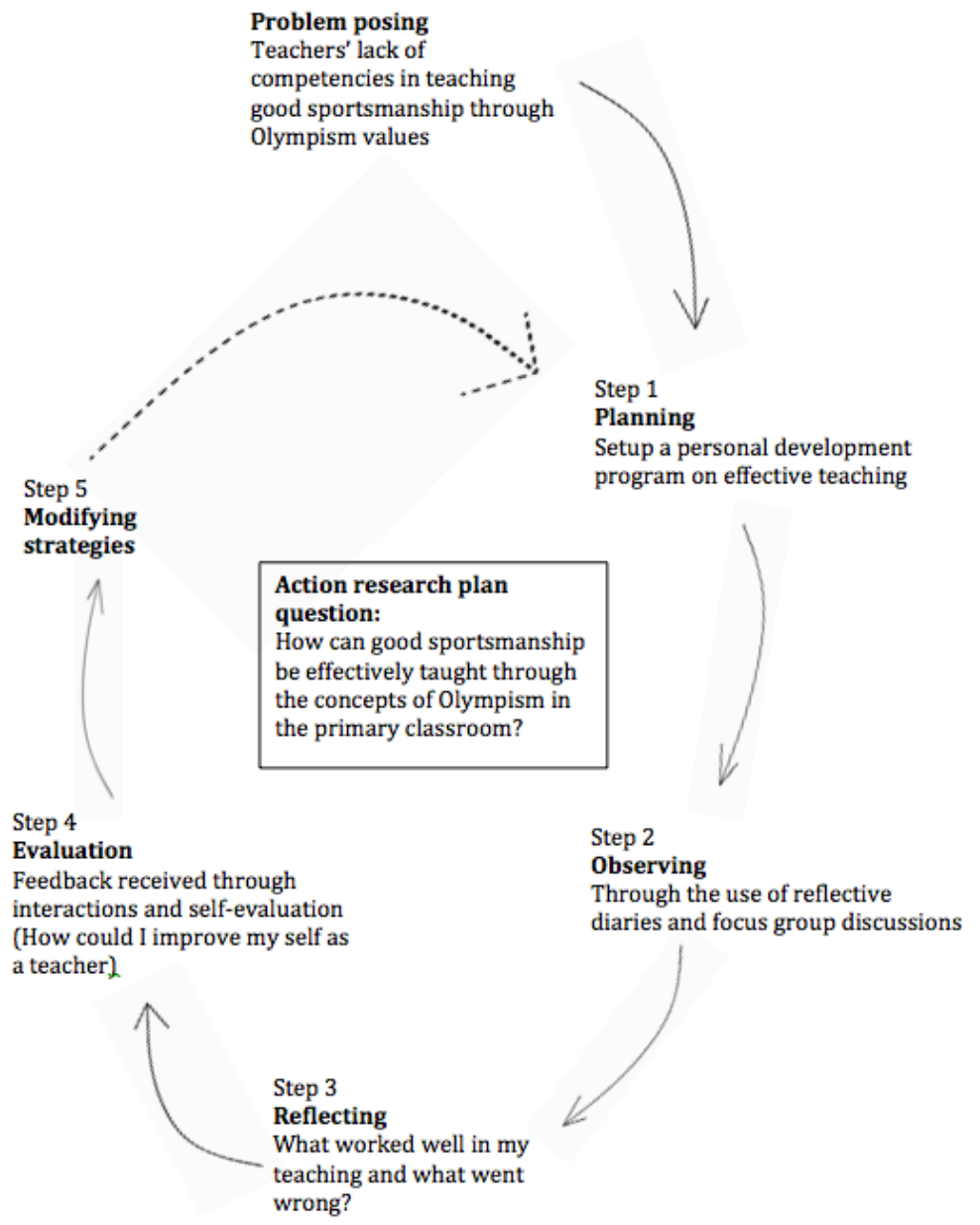

Figure 1. Action cycle 


\section{Participants}

Five Sri Lankan state primary schools from the list of Central Province Ministry of Education have been selected in this research. These schools were selected according to the researcher's convenience. There were only one PE and one grade five class teacher in these selected each school. Therefore, five primary (year five class teachers) and five physical education (PE) teachers in total, participated in this research. In order to identify the primary and PE teachers' needs and problems in teaching Olympism, a baseline survey was conducted throughout these five primary schools prior to the research implementation. The study combined the (year five) primary teacher and PE teacher of the each school to effectively teach Olympism to students at primary level. The primary teachers were designed as "teacher researchers" and were paired with the corresponding physical education teacher from the same school as a "critical friend". The primary role of these teachers was to improve students' skills, knowledge and attitudes on good sportsmanship through Olympism by conducting effective classroom activities. This was planned to be conducted during the physical education period once a week for up to 24 weeks (six months). The rationale for selecting the year five class teacher as the teacher researcher was that year five students are in the transitional period of moving on to secondary education, and they are at their best age to embrace the "Youth Olympic Games". The International Olympic Committee's (IOC) age limit for Youth Olympic Games is 14 to 18, and therefore this study increased young students' awareness of the concept of Olympism, and the Youth Olympic Games by the contained brain storming activities in the action research. This action research process also generated cognitive awakening of young children by enhancing knowledge, skills and attitudes of good sportsmanship.

As a lecturer in teacher education and the main researcher, I was responsible for implementing all sessions and utilising the same protocols and material for all schools. The timing of the interventions was strategically considered. To avoid tiring effects influencing participants' performances and to balance the same time for all groups, the interventions were planned at the same time of the day for all schools. These adjustments were implemented with the cooperation of all school principals. As the main researcher, I visited these schools for a considerable time.

At the beginning of this intervention process, I clearly stated that the individual participant's feelings and thoughts would be respected in this study. It was also explained that as an outsider, I would act as an initiator, implementer and observer in this research, and it was necessary to avoid utilising my personal values, beliefs and judgments. The whole process of this study was responsive and everyone was expected to consider each other's situation, feelings and thoughts. The participants and I agreed to work as a team throughout the intervention process by sharing knowledge, problems, questions, solutions, values, beliefs and responsibilities. 


\section{Procedure}

The baseline survey revealed that it is an essential requirement to train teachers on Olympism education and action research prior to the project. Therefore, teachers' workshop planning (except the Olympism work shop) was started in late 2009, and the Central Province Education Resource Centre in Kandy, Sri Lanka was selected as a possible workshop location. The reasons for selecting this location were easy accessibility for teachers and my familiarity (as the researcher) with this area. Permission was granted by the secretary of the Central Province Ministry of Education for these teacher training workshops. I contacted the relevant schools' principals and through them, the relevant teachers, and I administered the consent forms. Before the consent forms were signed all were fully informed about the research topic, the purpose and their role as participants, and the process of data collection. They were also informed that individual confidentiality would be highly respected in this study and that they could withdraw their participation at any time without any penalties.

At the first phase of these workshops, the importance and purpose of introducing and preparing an action research programme for each teacher researcher to implement in their own classroom was emphasised. How to build trustworthy relationships and mutual respect, rather than hierarchical power and control between the teacher researcher and the critical friend was also discussed. In this research, it was expected a research diary would be maintained by selected primary and PE teachers. Roland (1995) states that writing diaries encourage teachers to draw their personal understandings of specific ideas, which generated from theories and practices. Reflective diaries are a valuable source of data because they show not only "what I did" in action but also "what I learned" (McNiff and Whitehead, 1996). Accordingly, teacher researchers were encouraged to maintain a reflective research diary of day to day classroom activities and the critical friends were encouraged to write an observation report after each event. The standardised format of the reports focused on technical and critical learning. Technical learning that provided evidence of their gains in pedagogy, classroom management, and teaching approaches. Critical learning that also gave insight into professional critical development, attitudinal changes, facing challenges, and reflective practise in teaching.

Based on the main research question "How can good sportsmanship be effectively taught through the concepts of Olympism in the primary classroom?" teachers were advised to conduct their action research projects in their classrooms. Kemmis and Carr (1986) state that action research "is most rationally empowering when undertaken by participants collaboratively though it is often undertaken by individuals and sometimes in cooperation with outsiders". Therefore, in this research, meetings were held each month 
to support teachers and these meetings provided feedback for their action based teaching programmes as evaluated by the researcher. Prior to the action research process, the main teacher training workshop was carried out with the purpose of developing teachers' awareness for the Olympism curriculum. The following section will describe the nature of the first cycle conducted for teachers.

\section{Cycle one:}

Cycle one started with the main teacher training workshop for concepts of Olympism. This workshop was integrated with the 2009 annual National Olympic Academy (NOA) with the extensive support of the National Olympic Committee (NOC) of Sri Lanka. The 2009 annual National Olympic Academy was held in a hotel in the city of Bandarawela, Sri Lanka, in December. As the annual Olympic Academy was planned for five days residential, the teacher's workshop lasted for five days. PE teachers and the grade five class teachers from each school (ten teachers in total) participated in this workshop. Among them, two of the PE teachers were males and four of the grade five teachers were females. All the PE teachers had obtained their teacher training qualifications from the Uva National College of Education, Sri Lanka and all the primary teachers had obtained their teacher training qualifications from the Mahaweli National College of Education, Sri Lanka. The Central Province Ministry of Education granted these teachers duty leave for five days to participate in this workshop.

The workshop on pedagogy required a programme with an open-ended and flexible approach, because the needs of the participants would be unknown until the day of its launch (Hankin, 2008). A detailed programme for the workshop was distributed to the teachers at the beginning. The first day of the Olympism workshop focused mainly on the Greek antiquity. On the second day, teachers reviewed the historical development of Olympism, and the third day session emphasised Baron Pierre de Coubertin and his legacy for contemporary Olympism. The theme of the fourth day session was the clarification of contemporary Olympism concepts according to the IOC charter and perspectives on good sportsmanship. On the final day, teachers discussed the educational value of Olympism, the current practice of Olympism, the ways in which they could improve students' competencies in good sportsmanship and their enthusiasm for the Olympic Games. All these topics related to Olympism were designed by the researcher and the director of the National Olympic Academy of Sri Lanka.

A teacher training workshop should be shaped by academic and practical considerations (Hankin, 2008). Therefore, during the five-day period, each day had two academic sessions of two hours followed by an hour long 
discussion and two hours of a variety of practical sporting activities including netball, volley ball, football, badminton and table tennis (a total of six hours academic and two hours practical per day). A variety of video visual aids and Power-Point presentations were used in this workshop. Five Sri Lankan sport studies specialists conducted Olympism lectures. All of these specialists had more than five years experience in teaching in the NOA, and two of them had participated in the Joint International Session for Presidents or Directors of NOAs and Officials for NOCs conducted by the International Olympic Academy. At the end of each day, as the main researcher and implementer, I conducted two-hour long workshop for teachers about classroom action research. In this workshop, teachers were taught how to plan a classroom action research, the action cycles and how to conduct action research based on a focal problem. Printed materials related to all of these lectures were distributed to the participants. On the final day, an evaluation meeting was held with the participant teachers and they gave $80 \%$ points as the overall evaluation for workshops aims and objectives, content and delivery, interaction with teachers and use of resources. Subsequently, teachers went back to their classrooms and implemented their own action research on effective teaching of Olympism.

\section{Evaluation meeting one}

The first evaluation meeting was held after the first four weeks of the intervention, to report progress, discuss problems, and share successes. Overall, the teachers were enthusiastic about teaching good sportsmanship through Olympism to primary students. However, teachers' reflection diaries reported that there were many problems while teaching them. For instance teachers' reflection reports revealed:

"It was an interesting topic to teach in the primary classroom. Students were very enthusiastic and very inquisitive about learning this new concept. So, I had to prepare extra work for the introduction of these lessons. But I couldn't think of any extra practical work, because I always used to give paper work for my students"

"Students knew only about the Olympic Games. They had never heard of the concept of Olympism. I had to teach them the history from the beginning... and it was like telling a story during a physical education lesson"

"My students' knowledge about the Olympic Games was very low. They knew about the five rings, but not the fact that they symbolised five continents"

"Most of the students in my school come from a low socio-economic background. Most of them don't even have a TV at home. So, they haven't 
seen any documentaries about the Olympics. The only opportunity they get to know about the Olympics is through the opening ceremony of their annual sports meet"

"Students knew only about the five rings and the torch. They didn't know that good sportsmanship is essential to compete at Olympic level. I thought teaching them Olympism would be very difficult"

Teachers' reflection reports also revealed that before the initial training at the National Olympic Academy, primary teachers were not familiar with any information related to Olympism. Their knowledge was based only around the most recent Olympic Games. In contrast, PE teachers' knowledge about Olympic Games was very good but they were not knowledgeable about concepts of Olympism.

It was noteworthy that all the PE teachers were trained as secondary school teachers and not as primary level teachers.

"The PE teacher was trained as a secondary school PE teacher. So, it is very difficult for me to teach the primary students with him"

"This is the first time I have been involved in peer-teaching with a PE teacher. Teaching was quite a complicated process in the beginning because the PE teacher wasn't familiar with primary teaching and peer teaching"

However, some teachers were able to find solutions to this problem in their own way.

"I have realised that peer teaching is very important to teach a subject like Olympism. We can combine the subject expert and a teaching professional together. The only thing is we need to understand what we are teaching and how we are going to teach and who will be teaching"

"We need to allow teachers to practise and enable them to freely express themselves and identify their own weaknesses. This is what I did in my class"

At the first evaluation cycle, a number of points came out of the discussions:

(i) Teachers generally know little about Olympism, beyond what they obtain from the media about current Olympic Games. The Olympism Workshop had been very valuable to the participants.

(ii) Not surprisingly, the children's initial level of knowledge about Olympism and the Youth Olympics had been low. Therefore, teachers need to introduce the concepts of Olympism from the very beginning. 
(iii) The concept of Olympism was rarely addressed in schools, typically only at the opening ceremony of the annual sports meet. Therefore, teachers need to ensure that they provide more activities that will increase the practical knowledge of Olympism in order to encourage good sportsmanship.

(iv) While physical education teachers did indeed teach about the Olympic Games in their classrooms, the content of their lessons tended to be almost entirely on the history of the Olympic Games. Their knowledge of Olympism values, while extensive, was not necessarily comprehensive. Generally they taught only the theoretical perspectives of Olympism.

The teachers' self-assessment reports revealed that some teachers need further assistance in peer teaching. Therefore, in this cycle, teachers were advised to concentrate more on peer-teaching methods. In most schools the PE teacher was not familiar with peer teaching, but most of the primary teachers participating in this study had been involved in peer teaching previously. Therefore, the need for a one-day workshop related to the fundamentals of primary teaching and peer teaching for PE teachers in order to teach them the concepts of Olympism with primary teachers collaboratively was identified.

\section{Cycle two:}

The second cycle started with a one day teachers' workshop held two months after the previous workshop, with the collaboration of the Central Province Ministry of Education, Sri Lanka at the Central Province Education Resource Centre in the city of Kandy. All the teachers who had participated in the previous workshop attended this workshop.

Two College of Education lecturers contributed as resource persons in this workshop. These lecturers were qualified with master degrees and were fully competent in educational studies, having had much experience in primary teaching methods and researching about primary teaching-learning interactions. The workshop lasted eight hours with three sessions of two-hour lectures and two hours of practical activities. Printed materials related to these lectures were distributed to the participants.

The purpose of this workshop was to improve competencies in constructivist primary and peer teaching methods. Key concepts of primary and peer teaching principles and methods were emphasised. Guided exploration, consolidation and extension to develop Olympism curriculum teaching were mainly highlighted in this workshop. Teachers applied cognitive scaffolding when working with a student "to resolve a problem, carry out a task, or achieve a goal which would be beyond his unassisted efforts" (Wood, 1998, Bruner, 1986). Therefore, teachers were informed to be focus mainly on the 
problem-based teaching-learning process and allow students to be involved as knowledge producers. In this session, teachers experimented with Olympism teaching using different techniques of teaching. For instance, teachers were reminded about experiential learning and co-operative learning. Each session was designed to evoke teachers' intrinsic motivation and to develop abilities in Olympism education teaching in primary classroom settings.

The second part of this session was devoted to the expression of teachers' ideas on problems that arose in teaching the Olympism curriculum. Teachers' voices revealed that:

"It was not a problem to teach the concepts of Olympism; but the problem was how to teach good sportsmanship with practical experience"

"I taught them about how to use tolerance while doing sports. But it was very difficult to teach about tolerance while they were playing, and I had never done this before"

However, some teachers were confident in resolving their own problems in their classroom.

"I had the same problem and I tried several methods. Once, Icommanded students to stop playing when they were playing unethically. At that time, I explained why I had stopped them from playing and what was wrong and what concept of Olympism we needed to apply in that situation. Students were surprised and tried to find answers. Eventually, they discovered the correct answer. This method worked well in my teaching"

"I did conversely; when the whistle was blown they learned that there was no fair play in their team. So they tried to find the person who was not practising good sportsmanship. This was quite an experiential learning process for them"

"What I intended to do was to group them heterogeneously in accordance with their practical activities. So there was a good mixture of girls and boys with different abilities. Leadership was rotated between girls and boys. They started to respect each other. Surprisingly, their disruptive behaviour decreased and they worked co-operatively"

Resource persons were fully confident answering all the teachers' questions with solid subject knowledge and professional experiences. On the other hand, these resource persons pointed out some problems that might occur during the Olympism curriculum teaching and provided possible solutions. For instance, teacher training lecturers pointed out the important of tolerance for teachers while teaching about tolerance and how teachers needed to concentrate on students' individual learning skills. The importance of experiential learning 
at primary school level was also highlighted. At the end of the workshop, teachers were able to understand that the Olympism curriculum is based on a holistic consideration of the child's psychosocial and physical development. The overall evaluation for the workshop aims and objectives, content and delivery, interaction with teachers and use of resources from the participants was $80 \%$.

\section{Evaluation cycle two}

At the second reviewing cycle, teachers' action research reflective reports revealed that primary students were interested in talking and asking questions about good sportsmanship and they were enthusiastic to study about the concepts of Olympism. One teacher's reflective diary reported:

"I drafted my lessons so that within each group students would ask questions related to values of Olympism such as how to keep friendship while playing, and how to respect each other while playing. This strategy helped my students to express their ideas freely and to think critically",

Another teacher's reflective diary reported:

“I gave priority to my students' needs. Before I planned the next lesson, I asked my students' what their interests were; what games they wanted to play next week and what values (tolerance, respect for each other etc) they needed to be more familiar with, to succeed good sportsmanship"

This data illustrates that the teaching was very pleasing and the strategies involved were truly effective. Teachers' reflective reports also revealed that the teaching-learning process was more successful when concepts of Olympism combined with students' own cultural values.

"I always encouraged students by giving them constructive feed back. I believe that my positive reinforcement motivated students and kept them actively involved in learning"

Teachers reported that their students were enthusiastic about learning how to become a great athlete, and identifying the importance of avoiding bad sportsmanship. Most teachers were confident with their knowledge, attitudes and skills in Olympism concepts after participating in the National Olympic Academy sessions. However, some teachers were still unsure about selecting appropriate methods to teach different concepts of Olympism. For instance, teachers revealed that they were quite confused about teaching different Olympism values combining sporting activities.

"My action plan did not really work as well as I expected. Even though some students were prompt, many students were not able to understand 
good sportsmanship through Olympism. I used all methods but I need to try a different way of teaching"

It seems such teachers had used different teaching methods but had recognised those were not the appropriate methods to teach the lesson, and that they required guidance.

Another major problem that arose during the action research process was most of the primary teachers preferred classroom teaching while in contrast PE teachers preferred more practical activities outside of the classroom. In particular, most of the primary teachers disliked sun-burn so they abhorred practical activities outside. This situation created a problem, because practical activities are a compulsory requirement for physical education teaching. McTaggart (1991) emphasises that,

"Participatory action research is concerned simultaneously with changing both individuals and the culture of the groups, institutions and societies to which they belong. But it is important to emphasise that these changes are not impositions: individuals and groups agree to work together to change themselves, individually and collectively. Their interests are joined by an agreed thematic concern".

Therefore, teachers were advised to work collaboratively to reach the research goals. However, some teachers' reflective reports revealed that they had taught the same lesson by peer teaching successfully.

"The PE teacher and I were fully competent in teaching concepts of Olympism. Although I am a primary teacher, I love sports. So, our program went very well",

"As teachers we need to know what prevents teachers from actively participating in peer teaching. It seems that lack of comprehension or friendship could cause this. So it is very important to understand each other and stick together"

"Cultural understanding is very important to maintain the collaborative work. The primary teacher was a more experienced senior teacher, so I did occasionally give priority to her ideas. She felt humbled to be respected, so she respected my ideas in turn.

These teachers provided reciprocal guidance for teachers who had been unsuccessful in peer teaching. However, it was also found that some PE teachers' practical performance was lower than how they actually perceived the goals of Olympism teaching. After reviewing what other teachers had discovered on these issues, it was decided to conduct another one-day workshop for teachers to disseminate knowledge related to teaching methods. This workshop was particularly planned to emphasise peer teaching, and 
activity based primary teaching-learning topics. Teachers were requested to distribute more Olympism materials such as printed lesson plans and visual aids. The next section will demonstrate the process of the final cycle of this study.

\section{Cycle three:}

The final cycle followed on from the one-day teacher training workshop two months later and it was held at the same location, with the same resource persons and the same participants. The main purpose of this workshop was to collate teachers' reflections on teaching the Olympism curriculum. McNiff and Whitehead (2002) point out seven key characteristics of reflective teaching, the first being that "it implies an active concern with aims and consequences, as well as means and technical efficiency". Therefore, teachers' practical and technical interests were taken into account. They were reminded about peer teaching and activity based teaching methods. Through the exchange of experiences and reflection on these teachers were encouraged to evaluate their own strengths and weaknesses and solutions to the weaknesses were introduced.

The final session was also focused on individual teacher's formative evaluations of the workshops. The workshop activities were reflected on and analysed by the resource persons. A computer presentation of the summary of previous workshops was shown to the teachers. It was important to ensure that the team had clear aims and teaching-learning strategies to reflect on and evaluate the Olympism curriculum teacher training. The teachers provided their individual responses and feed back about their learning in Olympism curriculum teaching. The teachers were asked to consider:

(i) Whether the overall Olympism curriculum teacher training gave them a better understanding of Olympism teaching practise

(ii) Whether the teacher training activities helped them to understand about teaching good sportsmanship through the Olympism curriculum

(iii) Whether the teacher training activities were relevant to understand how to teach good sportsmanship through the Olympism curriculum

(iv) What difficulties they met with the Olympism curriculum teacher training

(v) Whether the Olympism curriculum learning could promote good sportsmanship among the Sri Lankan primary school students

The overall evaluation for the whole teacher training process was 90\%. Most of the teachers' responses focused on teaching strategies, workshop content and resources. However, everyone felt that all sessions achieved the aims and that 
teachers were more involved in the activities. The teachers accepted the idea of teaching good sportsmanship through the Olympism curriculum. The resource persons suggested that teachers should play a more active role in teaching the Olympism curriculum combining with other teachers. In this closing session I praised teachers for their contribution. These teachers' reflections helped the researcher to develop a successful Olympism curriculum intervention.

\section{Evaluation cycle three}

At the final reviewing cycle, teachers' action research reflective reports and self-assessment reports revealed that their students had made enormous gains in the knowledge, attitudes and skills required for good sportsmanship and in understanding the concepts of Olympism. Students' interest in Youth Olympic Games had also increased, and students had acquired possible opportunities for participating in school sports. Consequently, teachers were happy about their teaching when they observed their students' positive outcomes. An important finding emerged from the teachers' reflective diaries was that there were two patterns of growth in primary students' sportsmanship competencies. First, there was an increasing growth of students' competencies in good sportsmanship and secondly, there was a decrease in the evidence of bad sportsmanship. Teachers' reflective reports revealed that primary and PE teachers' peer teaching was most interesting and had made their career more enjoyable and memorable. It was also revealed that support from non PE teachers had a direct impact on the success of Olympism teaching. In particular, primary teachers were enthusiastic about teaching Olympism as a core subject in their primary curriculum. The relationship built between teacher researchers and critical friends at the beginning of the research was most helpful for strengthening the teaching-learning process.

\section{Discussion}

The purpose of this study was to improve effective teaching on good sportsmanship through Olympism education in the primary classroom. At the end of this programme, it was also expected that there would be an improvement in teachers' knowledge, attitudes and skills in classroom action research and that it would directly affect their ability to demonstrate effective Olympism education teaching competencies. One of the major findings of this study was that participants' personal development as teachers was greatly enhanced through this action based teacher training program, and the program worked as an 'eye-opener' for them. This was probably because the action based teacher training program conducted for teachers gave them new insights on teaching. The instructions they received were useful to improve skills in handling student-teacher relationships with confidence. Teachers, who understand teaching-learning problems through first-hand research 
experience, were more likely to be able to construct the social environment which provides effective learning for all students. This is supported by DeVries et al., (2002) who emphasise that the establishment of a co-operative, sociomoral atmosphere in the teaching-learning process such as opportunities to work together in groups, and exchange thoughts and ideas in situations where mutual respect is continually practiced, could enhance students' progress in constructivist learning.

Another interesting finding emerged from this study was that the positive support from other teachers (non PE) in the school directly enhanced effective teaching in Olympism education. One could that speculate the high demand for Olympic Games participation in society, and people's high interest in sporting involvement had influenced non PE teachers' attitudes towards sport, and made them more positive about involvement in this programme. Therefore, it is very important to integrate non-physical education teachers who are familiar with or interested in sport or Olympism with PE teachers. This study in Sri Lanka was a good example of teacher integration for introducing how to teach new subjects while sharing limited resources in different school cultures and enhanced sustainable development in sport education.

Scientists use "deductive logic by beginning with known scientific principles or generalisation, and deducting specific assertions that are relevant to a specific question. Inductive logic begins with experiences and result in conclusions or generalizations that are probably true" (Cohen et al., 2005). In this research, I tested an action based teacher training model by using the deductive logic of general observations to specific conclusions and the inductive logic from specific observation to general conclusions. However, it was found that progress depends on the nature of the teachers' competencies. In order to accomplish teacher competencies, it is important to enhance their knowledge, attitudes and skills through continuing teacher training workshops. This was completed during three action cycles in this study. It was also found that in order to succeed in teaching Olympism it must be integrated with a research based approach. Therefore, the action research method was useful for the promotion of the Olympism education teacher training.

Galluzo and Pankratz (1990) emphasise that a teacher education program "may be built on some leading principles that provides an idea of how we think about teaching and the teacher's work in the school". Teachers' critical insights in this study revealed that they have identified the ways in which the changes could be introduced to strengthen the classroom discourses. It is very important in developing Olympism education lessons to recognize the appropriate activities, using limited resources, different levels of effort required while teaching, and matching pedagogical areas with age levels. Teachers felt that they were free to adopt constructivist teaching methods in different circumstances in their own classroom culture while this action 
research was implemented. For instance, during the training process some teachers used questioning methods to empower students in critical thinking and finding answers with new insights into a focal problem. This is supported by the finding of Vyogotski (1978) that using questions for a constructivist teacher is important, because questions help students to move thinking forward and promote their reasoning skills. Reaffirming this argument, Brosio (2000) points out that a critical constructivist teacher should formulate questions that expose the conditions that promote social and educational advantage and disadvantage. It was also revealed in this study that some teachers were able to encourage students' interests while teaching. This is a very important way of building the trustworthiness and mutual understanding of the teaching-learning process. This is supported by the finding of DeVries et al., (2002) that a constructivist teacher needs to observe what students do spontaneously, and request students' ideas about what they want to learn, propose appealing activities and provide ample opportunities for students to make choices. These teaching methods were very useful to enhance teachers' professional development as they were making stronger approaches to explore the particular dynamics of their own classroom. Therefore, action research has provided possible opportunities for teachers to work as classroom researchers to enhance students' competencies on good sportsmanship through the Olympism education teaching-learning process.

\section{Conclusion}

To enable teachers to develop young children's good sportsmanship competencies, teachers should be fully competent in effective Olympism education teaching approaches. Therefore, the impact of using action research for effective teaching of good sportsmanship through Olympism at primary classrooms was examined in this study. This research was conducted in the Central Province, Sri Lanka, with a sample of five physical education and five primary teachers. These teachers worked together as teacher researchers and critical friends throughout the action research process. The results revealed some compelling information on how PE teachers teach Olympism, methods used for teaching, the improvisation of relationships with primary teachers, and the nature of problems occurred while teaching Olympism in primary classroom settings. Results showed that PE teachers generally did not recognise the appropriate Olympism teaching methods at first. However, by the end of third action research cycle, most teachers were competent in constructivist teaching and passionate about their Olympism teaching competencies. It was also revealed that positive support from non PE teachers directly impacted on successful Olympism teaching. The findings of this study provided an insight into the importance of continuing in-service teacher training for effective constructivist teaching in Olympism education with regard to promote good sportsmanship. Thus, it is a necessity to develop and conduct action research teacher training programmes for this purpose. 


\section{References}

Arnold, P. (1979). Meaning in movement, sport and physical education. London: Heinemann.

Binder, D. L. (2004). Teaching Olympism in schools: Olympic Education as a focus on values education. Alberta: Olympic Study Centre.

Binder, D. L. (2005). Teaching Olympism in schools: Olympic Education as a focus on values education. Barcelona: Centre d'Estudis Olimpics, University of Autonoma, Barcelona.

Brosio, R. A. (2000). Philosophical scaffolding for the construction of critical democratic education. New York: Lang.

Bruner, J. (1986). Actual Minds, Possible Worlds. Cambridge and London: Harvard University Press.

Campbell, A. and Groundwater-Smith, S. (2010). Introduction, Methodologies in Action Research: A Contested Area. Action Research in Education, (Vol II). London: Sage Publications.

Cohen, L., Manion, L. and Morrison, K. (2005). ( $5^{\text {th }}$ Ed). Research Methods in Education. London: Routledge.

Cropley, A., and McLeod, J. (1986). Preparing teachers of the gifted. International Review of Education, 32(2), 125-136.

Culpan, I. (2001). The pedagogy of neo-Olympism in a national physical education curriculum: The Greek connection. Paper delivered to International Olympic Academy Special Session. Olympia. Greece.

Culpan, I. (2007). Olympic education within physical education: Changing the pedagogy. Proceedings from the International Forum on Beijing Olympic Education. Humanistic Olympic Studies Centre at Remin University of China. 24-25 ${ }^{\text {th }}$ Nov. Pp. 136-154.

DeVries, R., Zan, B., Hildebrandt, C., Edmiaston, R., and Sales, C. (2002). Developing Constructivist Early Childhood Curriculum. New York: Teacher's College Press.

Elliott, J. (1991). Action Research for Educational Change. Milton Keynen: Open University Press.

Elliott, J. (2002). Collecting, Analysing and Reporting data in Action Research: Some Methods and Techniques. Paper presented at the Workshop for Teacher Training Agency: School based Research Consortia: Working and learning in Partnership. March $14^{\text {th }}$, Norwich, University of EastAnglia. 
Fernandez-Balboa, J. M. (1997). Knowledge base in physical education teacher education: a proposal for a new era. Quest, 49 (2), 161-181.

Galluzo, G. and Pankratz, R. (1990). Five attributes of a teacher education program knowledge base. Journal of Teacher Education, 41 (4), 7-14

Grupe, O. (1997). Olympism is not a system: It is a State of Mind. Olympic Review Feb/Mar, XXV.

Hankin, 1. (2008). Exploring African teachers' aspirations and the relevance of in-service workshops. In Clarkson, J., Bamber, P. and Bourke, L. (Eds). In Safe Hands: Facilitating service learning in schools in the developing world. Trowbridge: Cromwell Press ltd.

Hewett, V. M. (2001).Examining the Reggio Emilia Approach to Early Childhood Education. Early Childhood Education Journal, 29(2), 95100.

Kemmis, S., and Carr, W. (1986). Becoming Critical: Education, Knowledge and Action Research. London: Falmer Press.

Kincheloe, J. L. (2005). Critical Constructivism. New York : Peterlang primers Publishers.

Mcleod, J., and Cropley, A. (1989). Fostering Academic Excellence. Oxford: Pergamon Press.

McNiff, J., and Whitehead, J. (1996). You and your action research project. London: Routledge.

McNiff, J., and Whitehead, J. (2002). Action Research: Principle and Practice $\left(2^{\text {nd }} E d\right)$. London: Routledge.

McTaggart, R. (1991). Principles for participatory Action Research. Journal of the participatory action Research Network (1), 29-44.

Ministry of Education, Sri Lanka, (Central Province) (MOECP). (2008). Report of the Teachers' Need Analysis 2008, Kandy: Ministry of Education.

Muller, N. (2004). “Olympic Education” University Lecturers on the Olympics. Centre d' Estudis Olympics, Universitat Autonoma de Barcelona (2004): 7: Retrieved on 3.4.2008 from http://olympicstudies.uab.es/lec/pdf/ muller.pdf.

Roland, C. (1995). The use of Journals to promote reflective thinking in prospective Art teachers. In L. Galbrain (Eds). Pre-service Art Education: Issues and practice. Virginia: NAEA 
Ruiz, B., and Fernandez-Balboa, J., (2005). Physical education teacher educators' personal perspectives regarding their practice of critical pedagogy. Journal of Teaching in Physical Education, 24(3), 243-264

Taylor, P. (1998). Constructivism: Value added. In: B. Fraser and K. Tobin (Eds), The International handbook of science education, Dordrecht, The Netherlands: Kluwer Academic

Vygotsky, L. S. (1978). Interaction between learning and development. Mind in society: The development of higher mend processes. Cambridge: Harvard University Press.

Williams, A. (2000). Research and the Primary School Teacher. In A. Williams (Eds), Primary School Physical Education: Research into Practice. London: Routledge. Pp.1-15

Wood, D. (1998). How Children Think and Learn: The Social Contexts of Cognitive Development ( $2^{\text {nd }} E d$ ). Oxford: Blackwell

Wood, D., and Attfield, J. (1996). Play, Learning and the early childhood Curriculum. London: Paul Chapman Publishing

\section{Acknowledgement}

Author would like to thank the President, Mr Hemasiri Fernando, and Secretary General, Mr Maxwell de Silva, of the National Olympic Committee of Sri Lanka for their amicable support while conducting this study in Sri Lanka. 